\title{
Reproductive and Pollination Biology of the Endemic Hawaiian Cotton, Gossypium tomentosum (Malvaceae) ${ }^{1}$
}

\author{
John M. Pleasants ${ }^{2,3}$ and Fonathan F. Wendel ${ }^{2}$
}

\begin{abstract}
Gossypium tomentosum is a cotton species endemic to the Hawaiian Islands. We studied several aspects of its reproductive biology, including potential pollinators, floral biology, and diurnal and seasonal flowering phenology. Flower visitors were observed in G. tomentosum populations on O'ahu, Kaho'olawe, and Maui. Primary visitors were introduced species, honeybees and carpenter bees, both of which were pollinating the flowers. No native bee species were seen visiting flowers. In examining floral biology we found that in some cases $10 \%$ of flowers had styles that were as short as the anthers or were recurved toward the anthers. In the greenhouse, in the absence of pollinators, these flowers were the only ones that set fruit. Flowering of G. tomentosum commences in January and February, following the rainy season, peaks in May, and may continue into August and September. In one year, after higher than average precipitation during the rainy season, there was a greater abundance of flowering, and flowering persisted later into the year. Transgenic varieties of commercial cotton, $G$. hirsutum, are grown in Hawai'i and are interfertile with $G$. tomentosum. Honeybees and carpenter bees are also known pollinators of commercial cotton. Because these pollinators are long-distance foragers, we estimate that transgenic cotton fields would have to be greater than $10 \mathrm{~km}$ from a G. tomentosum population to prevent gene flow.
\end{abstract}

A MAJOR CONCERN about the long-term persistence of many plant species is the decline in insect pollinators resulting from human activity (Beismeijer et al. 2006). Endemic plant species on islands are especially vulnerable because of population reduction and fragmentation that may no longer support their pollinators and because of the impact of introduced pollinators on native pollinator species (Cox and Elmqvist 2000). Gossypium tomentosum Nuttall ex Seeman (Malvaceae), locally referred to as ma'o, is a cotton species endemic to the Hawaiian Islands. It historically has been relatively common in well-

${ }^{1}$ The Environmental Protection Agency provided financial support for this research. Manuscript accepted 29 January 2009.

2 Department of Ecology, Evolution, and Organismal Biology, Iowa State University, Ames, Iowa 50011.

${ }^{3}$ Corresponding author (e-mail: jpleasan@iastate.edu).

Pacific Science (2010), vol. 64, no. 1:45-55

doi: $10.2984 / 64.1 .045$

(C) 2010 by University of Hawai'i Press

All rights reserved drained volcanic loams on the leeward side of the major islands of the archipelago except Hawai' $i$ and Kaua' $i$ (there is some evidence that it was once present on Kaua'i) (Stephens 1964). Many populations of this species have disappeared due to coastal development. An additional concern for $G$. tomentosum is that Hawai' $i$ is commonly used as a nursery for the improvement of commercial cotton, with which $G$. tomentosum is fully interfertile (Meyer and Meyer 1961; J.F.W., pers. obs.). Commercial cotton consists primarily of Upland cotton ( $G$. hirsutum) and to a lesser extent Pima cotton ( $G$. barbadense). The majority of the cotton raised in nurseries is transgenic $G$. hirsutum (Bt cotton and Roundup-Ready cotton). Cross-pollination of $G$. tomentosum with commercial cotton could compromise the genetic integrity of the species, and the introgression of transgenes might alter intra- and interspecific competitive relationships, confer an advantage that could lead to new weedy species, or in some other way alter evolutionary trajectories (Ellstrand et al. 1999). 
There have been no studies documenting the pollinators of $G$. tomentosum. Swezey (1935), in a survey of insects associated with G. tomentosum, collected two species of megachilid bees (nonnative species) from flowers. Stephens (1964) never saw any visitors to $G$. tomentosum flowers. He did observe honeybees and carpenter bees in the vicinity of some G. tomentosum populations, but those bees were visiting other plant species. $\mathrm{He}$ speculated, however, that infrequent visits by honeybees might have been responsible for producing two hybrid populations between G. barbadense and G. tomentosum he observed on O'ahu. Fryxell (1979) speculated that the native pollinator might be a moth, based on the following reasoning. First, he assumed that there must be a native pollinator because the fact that the style was exerted meant that no self-pollination could occur and therefore a pollinator would be needed for seed set and the persistence of the species. Second, he noted the absence of a dark spot at the base of the petals of $G$. tomentosum flowers; this spot is found in almost all other members of the Gossypieae, the cotton tribe, and serves as a nectar guide for bees. The absence, he said, indicated a nonbee pollinator. He also noted that $G$. tomentosum flowers stay open through the night, which indicates a pollinator active in the evening, such as a moth. This makes it different from the commercial cottons, and indeed all wild species of Gossypium, in which flowers open in the morning. The seasonal flowering phenology of $G$. tomentosum has also not been well studied. Stephens (1964) suggested that there may be little seasonality to flowering and indicated that some individuals could be found in flower at any time during the year.

The purpose of our study was to identify the pollinators of $G$. tomentosum and characterize aspects of its reproductive biology including diurnal and seasonal phenology and floral biology.

\section{MATERIALS AND METHODS}

Populations were examined on the islands of O‘ahu, Maui, and Kaho'olawe. Each popula- tion consisted of at least several hundred plants. The O'ahu population, referred to as Sandy Beach, is located on the southeastern corner of the island near Makapu'u Point. The population is east of Waikiki along Kalaniana'ole Highway past Sandy Beach Park and the golf course entrance. It is south of the road near mile marker 9 where the road begins to bend to the north and just before the pulloff to the trail to Makapu'u Point. The Maui population is located on the southwestern side of the western lobe of Maui. It is near the 14-mile mark on the Lahaina road (no. 30) near Olowalu and across the road from Camp Pecusa. The population is in the hills to the north of the road. On Kaho'olawe we examined scattered populations on the southwestern corner of the island in the vicinity of Lae o Kealaikahiki.

In mid-January 2003 we visited the Sandy Beach, Maui, and Kaho'olawe populations. At that time the flowering season was just beginning. In May 2004 we revisited the Sandy Beach and Maui populations. At that time both populations had abundant flowering.

During site visits several focal clusters of plants were observed from early morning to late afternoon over 1-3 days. The identity and activity of all flower visitors were observed. Visitors that could not be readily identified were collected for later identification. The ability of flower visitors to pollinate flowers was determined by examining a virgin flower immediately after a visitor had left. The presence of pollen on the stigma was taken as evidence that the visitor was indeed a pollinator. Virgin flowers were ones that had not been visited since the flowers opened that morning.

Observations were made of several floral characteristics, including the time of day that flowers opened. We observed that for some flowers the style was not completely elongated. Instead, the style recurved such that in some cases the stigmatic surface made contact with the anthers. We referred to this condition as "nonexserted." Fifty or more flowers were examined at each site to determine the frequency of nonexserted styles. We also monitored flowers of $G$. tomentosum in the 
Pohl Conservatory greenhouse at Iowa State University for this same suite of characteristics.

Flowers with nonexserted styles could potentially be self-pollinating in the absence of pollinator visits because this species is selfcompatible (Stephens 1964). We investigated the possibility of self-pollination using a single plant growing in the Pohl Conservatory at Iowa State University, which is insect-free. Flowers were tagged, noting date of opening, whether the style was exserted above the anthers, and whether pollen was observed on the stigma. Flowers that set fruit retained their tags, whereas those that did not set fruit abscised along with their tags, and data for those flowers were not recorded.

Seasonal flowering phenology was examined over $2 \mathrm{yr}$, from near the beginning of the 2003 flowering season (mid-February 2003) to the end of the 2004 flowering season (late August 2004), at the O'ahu and Maui sites. We also obtained information on seasonal precipitation at those sites to explore whether precipitation was related to the timing or abundance of flowering.

The O'ahu population was visited once a month by a local person, and the number of open flowers, closed flowers (flowers that bloomed the previous 1-2 days), flower buds, and occasionally fruits was counted on 20 marked plants. Precipitation records for the site were obtained from the Western Regional Climate Center (www.wrcc.dri.edu) monitoring site located at Waikìkī, about $16 \mathrm{~km}$ east of the Sandy Beach population. Average precipitation data were also obtained from that source. The average precipitation data covered the period 1 January 1965 to 30 September 2004.

The Maui population was monitored approximately every 3 weeks by a local person. The number of open flowers was counted on 20 marked plants. In addition, local daily precipitation was monitored. Average precipitation records for the site were obtained from the Western Regional Climate Center (www.wrcc.dri.edu) monitoring site located at Lahaina, about $9 \mathrm{~km}$ miles northwest of the Maui population. The average precipita- tion data covered the period 4 October 1949 to 31 October 2001.

RESULTS

\section{Floral Biology}

Flowers open in the morning, when sunlight strikes the petals. Anthers can be seen to dehisce shortly thereafter, typically within $15-$ 30 min. Flowers remain open only for part of 1 day; typically by late afternoon the flowers have begun to senesce, contrary to the observations of Frxyell (1979), who claimed that they remained open into the evening. Unvisited flowers did not have pollen on the stigmatic surfaces except for flowers with nonexserted styles (see later in this section).

On our January visit we observed that some flowers had recurved styles such that the style curved back down and sometimes made contact with the anthers. Stephens (1964) also noted that some flowers had recurved styles. We observed this "nonexserted" condition in the O'ahu, Kaho'olawe, and Maui populations, but the frequency of this condition was only quantified in the Maui population, where $10 \%$ of flowers had styles that were nonexserted $(n=374)$. On the May visit, during peak flowering, we found no flowers with nonexserted or recurved styles in either the O'ahu or Maui populations.

In the greenhouse, where flowers were tagged noting whether styles were exserted or not, of the 31 flowers that set fruit, 26 had nonexserted styles and had pollen on the stigma. Three flowers that set fruit had exserted styles but had pollen on the stigma, and two flowers that set fruit had exserted styles with no pollen observed on the stigma (pollination of these flowers may have been the result of the watering activities of greenhouse workers). In general then, it appears that fruit set can occur in the absence of pollinators but only if the flowers have nonexserted styles. Because we did not record data from flowers that abscised we cannot say what proportion of flowers had nonexserted styles or what proportion of flowers with nonexserted styles set fruit. 
Flower Visitors, fanuary 2003 Visit

In the O'ahu population small carpenter bees, Ceratina sp. nr. dentipes Friese (Roy Snelling, pers. comm.), a nonnative species, were visiting $G$. tomentosum flowers. They were probing at the base of the petals where the nectaries are located. Because of their small size (about $7 \mathrm{~mm}$ body length) they would not be likely to make contact with the anthers and the stigma, and we were unable in the field to verify that they could pollinate the flowers. However, a microscopic examination of several collected individuals showed that they did have pollen on their bodies and so could have been responsible for some pollination. Honeybees (Apis mellifera, a nonnative species) were observed on some flowering shrubs in the vicinity of the site, but none appeared to be visiting $G$. tomentosum. About 8.4 $\mathrm{km}$ north of the Sandy Beach population near Waimānalo we found a planted population of G. tomentosum along a canal embankment. The flowers were being visited by a number of honeybees. The honeybees had G. tomentosum pollen on their bodies and were contacting the stigma, so we can presume that they were pollinating the flowers. We encountered another planted population of $G$. tomentosum near Ka'ena Point, on the westernmost part of the island. Bees from the same species of Ceratina were visiting those flowers, and, although we saw honeybees in the area, we did not observe the latter to be visiting $G$. tomentosum.

In the Maui population a number of large carpenter bees, Xylocopa (Neoxylocopa) sonorina F. Smith, a nonnative species (Daly and Magnacca 2003), were visiting the flowers. The bees were covered with $G$. tomentosum pollen and were clearly contacting the stigma. A bee would enter the flowers headfirst with its abdomen contacting the staminal column and the style and stigma. As it gathered nectar from the flowers it rotated around the staminal column, keeping its abdomen pressed to it. Inspection of flowers just visited by carpenter bees showed that stigmas had pollen on them. By 1315 hours $90 \%$ of flowers had pollen on the stigma $(n=277)$. Several hon- eybees were also observed visiting the flowers for nectar.

On Kaho'olawe G. tomentosum was visited by a large array of species including honeybees, the Ceratina bee species observed on O'ahu, several different unidentified butterflies, and the nonnative Monarch butterfly (Danaus plexippus). There were few other plant species flowering at the time. We did not observe stigmas of flowers after visits by these species, so we cannot identify which were pollinators, other than honeybees.

\section{Flower Visitors, May 2004 Visit}

In the $\mathrm{O}^{\prime}$ ahu population honeybees were observed visiting flowers. The bees' heads were yellow with pollen, and after the bees visited flowers pollen could be seen on the stigmatic surfaces. No other visitors were seen. In the Maui population honeybees were observed visiting flowers but illegitimately. A bee would land on the outside of the petals and stick its proboscis between the petals to get to the nectar. Thus they were not contacting the anthers or style. We observed flowers that had been visited in that way, and none had pollen on the stigma. Many other plant species were flowering at that time. Carpenter bees were seen visiting some of these other flowering species but not G. tomentosum.

Honeybees are common on all the islands (Snelling 2003). In Hawai'i there are 7,000 commercial colonies in addition to colonies kept by individual beekeepers and feral colonies (K. M. Roddy and L. Arita-Tsutsumi, http://www.hawaiibeekeepers.org/history.php). The large carpenter bee species, Xylocopa sonorina, and the small carpenter bee, Ceratina dentipes, are present on all the main islands (Snelling 2003).

\section{Flowering Phenology}

Figure 1 shows the flowering phenology for the Sandy Beach (O'ahu) population in 2003 and 2004, and Figure 2 shows the phenology for the Maui population. For the Sandy Beach population the peak of flowering occurred in May in each year. For the Maui 


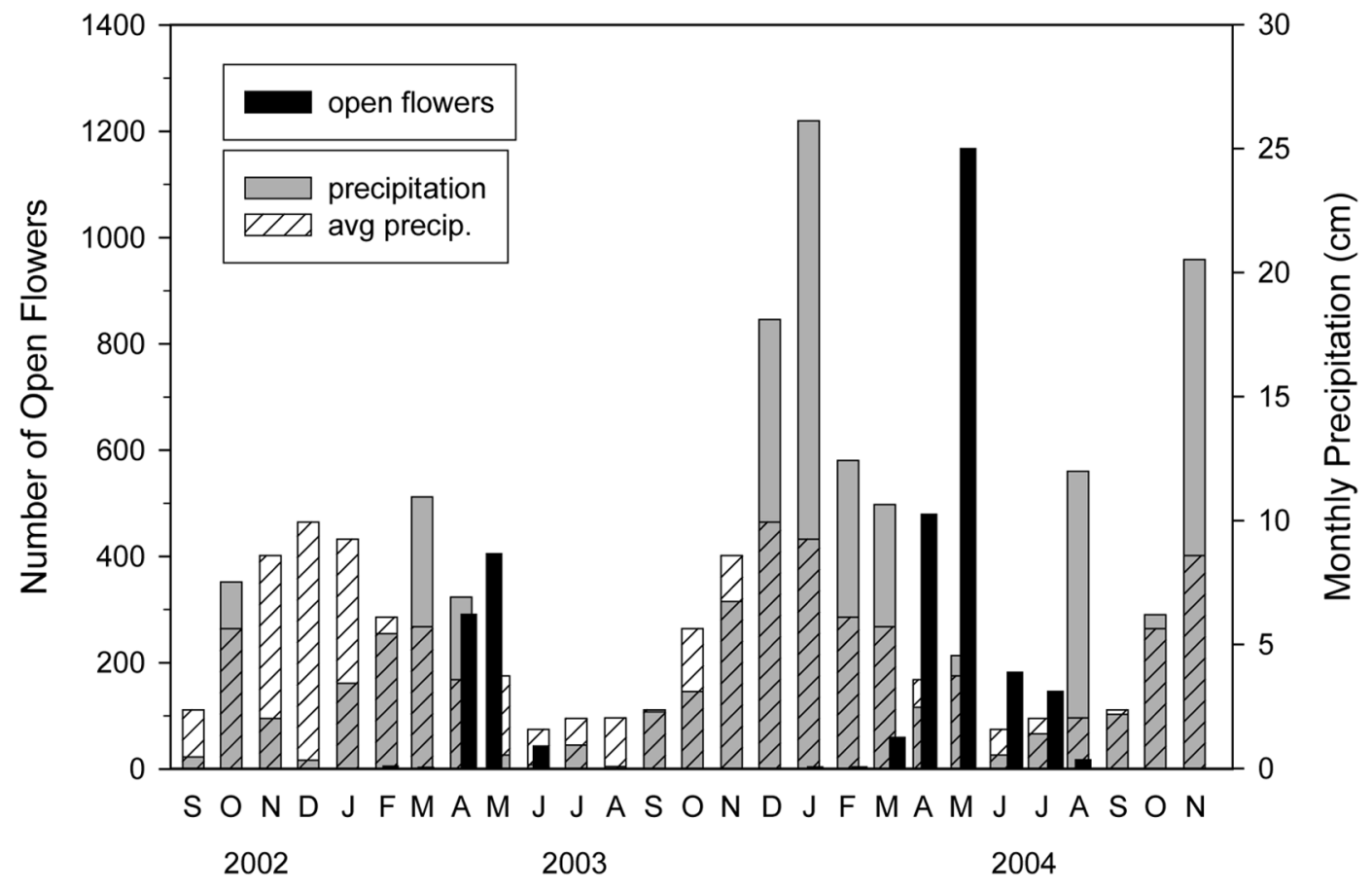

\section{Date}

FIGURE 1. Flowering phenologies for the O'ahu population in 2003 and 2004, with monthly precipitation totals (before 2003 and through 2004) and average monthly precipitation for the last $40 \mathrm{yr}$.

population, the peak of flowering occurred in April in 2003 and in May in 2004. This is in contrast to Stephens' (1964) suggestion that there might be little seasonality to flowering. In the Pohl Conservatory at Iowa State University, which is at a temperate latitude, peak flowering for $G$. tomentosum occurs twice per year, in the autumn (early November) and late winter (mid-February), when the day length equals about $11 \mathrm{hr}$.

There were two major differences between the 2003 and 2004 flowering seasons. First, the 2004 season continued much longer than the 2003 season. In 2003 plants ceased flowering by mid-June, whereas in 2004 plants continued to flower through August. However, plants began flowering sooner in 2003 than in 2004. Second, the number of open flowers on the 20 monitored plants was much greater in 2004 than in 2003. At the peak for Sandy Beach there were 405 open flowers in 2003 and 1,167 open flowers in 2004, almost three times as many. At the peak for Maui there were 145 open flowers in 2003 and 575 open flowers in 2004, almost four times as many.

The differences in phenology and flower abundance between 2003 and 2004 are likely related to precipitation differences. Figures 1 and 2 show the precipitation for each month and the average precipitation for the last 40$50 \mathrm{yr}$. In general, flowering begins after the winter rains that peak in December and January. The winter rains were below average before the 2003 season but were well above average before the 2004 season. This may have contributed to the prolonged flowering season in 2004. The cumulative rainfall for 


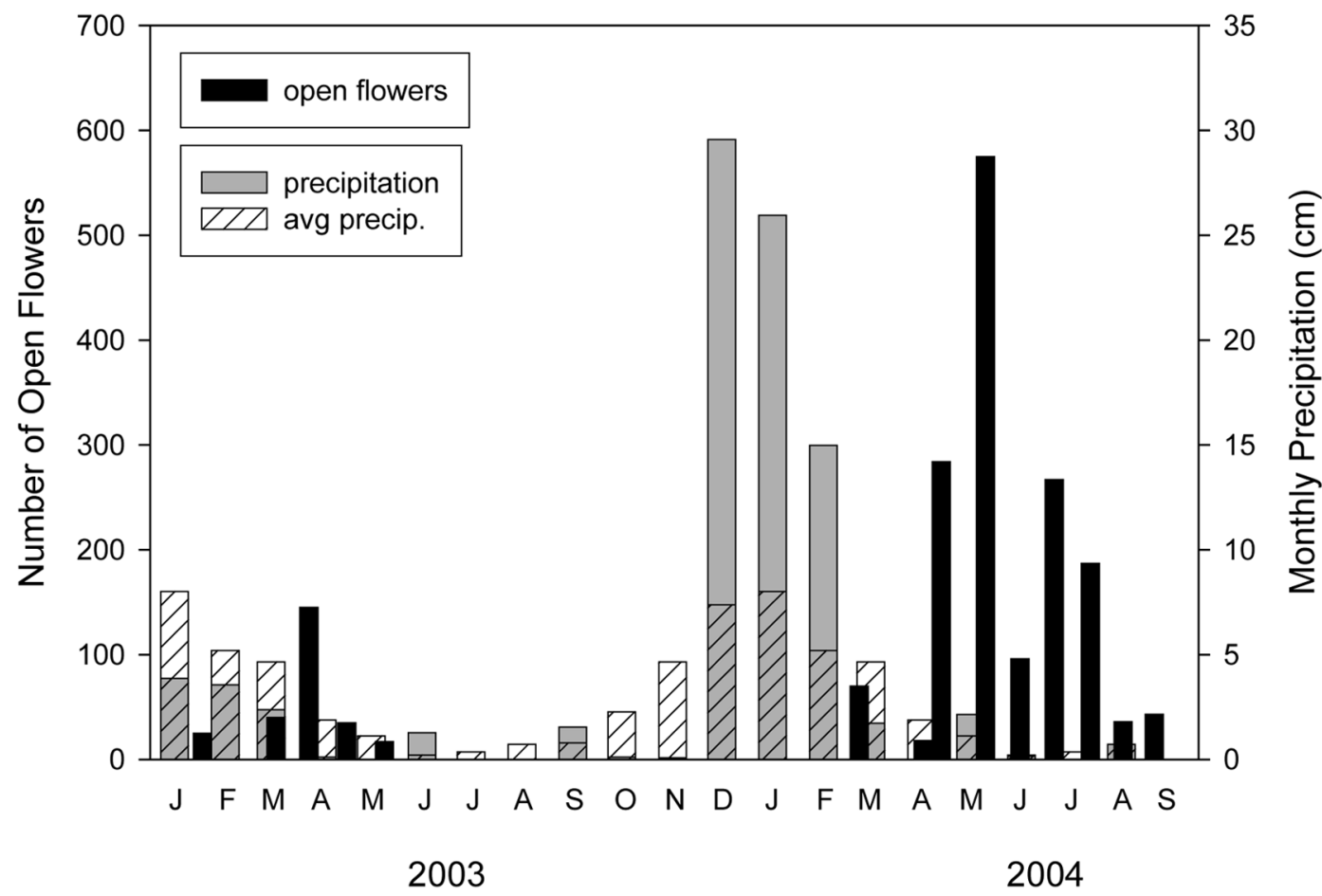

Date

Figure 2. Flowering phenologies for the Maui population in 2003 and 2004, with monthly precipitation totals for those years and average monthly precipitation for the last $50 \mathrm{yr}$.

the months of September through March can be used as an indicator of environmental conditions going into the main part of the flowering season. For the $\mathrm{O}^{\prime}$ ahu population there was $30.2 \mathrm{~cm}$ of rainfall from September 2002 to March 2003 and $79.5 \mathrm{~cm}$ from September 2003 to March 2004. This nearly threefold increase in precipitation from the 2003 flowering season to the 2004 flowering season corresponds to the nearly threefold increase in flower production from 2003 to 2004. This same comparison could not be made for the Maui population because precipitation records before 2003 were unavailable.

Fruit production was measured in the O'ahu population during the month of July. On the 20 focal plants there were a total of 417 fruits in 2003 and 965 fruits in 2004, evidence that a substantial amount of pollination had occurred (there is approximately a 2- month lag between flowering and the appearance of mature fruits).

\section{DISCUSSION}

Both in the field and in the greenhouse a small percentage $(10 \%$ or less) of flowers was observed with nonexserted styles. Measurements of flowers on greenhouse plants showed that there were two types of flowers with nonexserted styles, one with recurved styles and the other with a linear style that was not fully exerted, such that the stigmatic surface was included in the anther zone. To our knowledge this phenomenon has not been reported in any other Gossypium species. Klips and Snow (1997) found that in a Hibiscus species, another member of the Malvaceae, there was facultative recurvature of the stylar branches, resulting in self-pollination, 
if the flower was not pollinated. We noted that in the greenhouse $G$. tomentosum plants were likely to have a few nonexserted flowers when they began flowering, but that by the middle of their flowering period all flowers had exserted styles. This follows the pattern observed in the field. Perhaps this floral feature is an adaptation to ensure seed set when pollinators are scarce.

We observed a variety of floral visitors to $G$. tomentosum. The two species that we observed that could clearly be considered to be pollinators were the honeybee and the large carpenter bee. Assigning them pollinator status is based on the fact that their visits led to the deposition of pollen on the stigma. However, honeybees were not always pollinators; in the Maui population in May 2004, honeybees were visiting the flowers illegitimately. We cannot confirm that the smaller carpenter bee, Ceratina dentipes, is a pollinator of G. tomentosum.

Stephens (1964) reported that $G$. tomentosum flowers produce very little or no nectar although nectaries are anatomically present. Gossypium tomentosum lacks the foliar and extrafloral nectaries found in G. birsutum and all other Gossypium species (Meyer and Meyer 1961). Although we did not measure nectar production in G. tomentosum flowers, the behavior of the honeybees in particular suggests that they were foraging for nectar. Honeybee foraging behavior is distinctly different when they are collecting pollen than when they are collecting nectar. There were also some honeybee individuals that were collecting pollen. Individuals of Ceratina dentipes were foraging at the base of the petals, where the nectary is located, not near the anthers. The behavior of the large carpenter bees also indicated foraging for nectar. Illegitimate foraging, where the bee lands on the outside of the petals and sticks its proboscis through the edges of the petals, was observed in both honeybees and carpenter bees, and also indicates nectar foraging. The visits by butterflies that we observed also support the thesis that nectar is being produced because butterflies only visit flowers for nectar. It is possible that nectar production declines seasonally as plants are further removed temporally from the wet sea- son that precedes flowering. We have measured nectar production in the greenhouse using the techniques of McKenna and Thomson (1988) and found that flowers do produce small amounts of nectar.

There was considerable seasonal variation and site variation in visitors to $G$. tomentosum flowers. In January 2003, at the beginning of the flowering season, honeybees were visiting $G$. tomentosum flowers in the study populations on Kaho'olawe, Maui, and on some G. tomentosum plantings on $\mathrm{O}^{\prime}$ ahu. In May 2004, at the peak of the flowering season, honeybees were visiting $G$. tomentosum flowers in the O'ahu study population (legitimate visits) and were also visiting flowers in the Maui population, but illegitimately.

In January of 2003 large carpenter bees (Xylocopa sonorina) were making frequent visits to G. tomentosum flowers in the Maui population but were never seen at any other site at any time. Carpenter bees were also seen in May of 2004 at the Maui population, but they were visiting flowers of other species, not $G$. tomentosum. In January of 2003 small carpenter bees (Ceratina dentipes) were found visiting $G$. tomentosum flowers in the O'ahu population and flowers in another planted population on $\mathrm{O}^{\prime}$ ahu. They were also found visiting G. tomentosum flowers on Kaho'olawe but not in the Maui population. In May of 2004 these bees were not found at any site.

There are several things that might account for the temporal differences in visitation to $G$. tomentosum flowers. In January, early in the flowering season for $G$. tomentosum, there are few other plant species in flower (pers. obs.), so G. tomentosum may attract the attention of any bees present at that time. In May, when many other plant species are in flower, the flowers of G. tomentosum may be less preferred. For Ceratina dentipes, its widespread presence in January but absence in May could reflect a seasonal aspect of its life cycle. Honeybees and large carpenter bees, Xylocopa, have a more continuous presence throughout the $G$. tomentosum flowering season.

Neither honeybees nor the large and small carpenter bee species are native to the Hawaiian Islands (Snelling 2003), which begs the 
question as to what the native pollinator might be. Fryxell (1979) speculated that the native pollinator might be a moth based on reasoning described earlier but mostly because of his presumption that flowers opened near dusk. This clearly is a mistaken view of the floral phenology, and in fact we have never observed $G$. tomentosum flowers in the field or in the greenhouse that remained open into the evening hours. So we can dismiss the notion that a moth is the native pollinator.

This leaves native bees as a potential original pollinator. The only native bees in $\mathrm{Ha}$ wai' $i$ are members of the genus Hylaeus (subgenus Nesoprosopis [Colletidae]), which consists of about 60 species endemic to the Islands (Daly and Magnacca 2003). These are solitary bees about 1.5-2.5 times larger than Ceratina (Daly and Magnacca 2003). They have been little studied but may be important pollinators in native Hawaiian ecosystems (Magnacca 2007). It is possible that one or more species of this native Hawaiian bee group is the original pollinator of $G$. tomentosum. The fact that we did not observe any native bee visitors could mean that such bees are not the native pollinator or that the native pollinator bee species have been extirpated. It is interesting that the nonnative bee species, although they may have caused the extinction of the native pollinator, have now taken over the pollinator role with much success.

Gossypium tomentosum can persist in the absence of insect pollination by virtue of being long-lived (based on the size of some of the plants observed the life span must be many decades) and its capacity for self-pollination. In fact it may have been necessary for it to persist in this way for tens or hundreds of thousands of years after colonizing the Hawaiian Islands. If a member of the Hylaeus bee group is indeed the original pollinator, evidence indicates that these bees did not colonize the island until 500,000-700,000 yr ago (Magnacca and Danforth 2006), whereas G. tomentosum may have colonized as much as a million years ago (Wendel and Cronn 2003).

The honeybees and carpenter bees observed to be pollinating $G$. tomentosum flowers are also known pollinators of cultivated cot- ton flowers (Moffett 1983). Consequently there is the potential for gene flow between commercial cotton and G. tomentosum depending on phenological overlap and spatial proximity. Diurnal phenological overlap certainly occurs because $G$. tomentosum and commercial cotton both have flowers that open in the morning and are receptive for just 1 day. Commercial cotton may be grown in Hawai' $i$ at any time of the year, and thus phenological overlap can be avoided only if commercial cotton is flowering between September and January, when $G$. tomentosum is not blooming.

The spatial proximity between $G$. tomentosum populations and commercial populations that could lead to gene flow will depend on how far pollinators can travel between populations. Pollinators with a narrowly circumscribed foraging area are less likely to cause gene transfer to nearby populations than are more wide-ranging pollinators. The two major pollinators we observed, honeybees and carpenter bees, are noted for long-distance foraging. For one honeybee colony studied, the mean distance between a foraging patch and the hive was $2 \mathrm{~km}$, but some colonies' patches were $10 \mathrm{~km}$ from the hive, and the circle enclosing $95 \%$ of the colonies' foraging area had a radius of $6 \mathrm{~km}$ (Seeley 1985). Little is known about carpenter bee foraging distance, but they are similar in size and flying ability to bumblebees (genus Bombus). Osborne et al. (1999) found that Bombus terrestris occasionally travels more than $600 \mathrm{~m}$ from the nest. Darvill et al. (2004) confirmed this but showed that Bombus pascuorum rarely forages more than $300 \mathrm{~m}$ from the nest. A study on foraging by carpenter bees found that they visited flowers as far as $6 \mathrm{~km}$ from their nest and could travel up to $10 \mathrm{~km}$ (Pasquet et al. 2008).

Allen Van Deynze and Kent J. Bradford (pers. comm.) measured pollen dispersal from an herbicide-resistant cotton source field to neighboring nontransgenic commercial cotton fields. Pollen transfer (an average of $0.05 \%$ ) could still be detected at $0.6 \mathrm{~km}$, the greatest distance they examined. In a study on a noncotton species, Reiger et al. (2002) found that pollen-mediated gene flow occurred up to $3 \mathrm{~km}$ from large-scale 
herbicide-tolerant canola fields into neighboring commercial canola fields.

These gene-flow studies, along with information on the long-distance foraging habits of honeybees and probably carpenter bees as well, suggest that gene transfer via pollen dispersal could occur if populations of transgenic cotton were within $0.6 \mathrm{~km}$ of a $G$. tomentosum population and perhaps even farther away. No studies have examined the possibility of gene transfer beyond $0.6 \mathrm{~km}$, but given that honeybees can forage over $10 \mathrm{~km}$ from their hive, populations of transgenic cotton and populations of $G$. tomentosum would have to be separated by at least $10 \mathrm{~km}$ to be certain that there would be no gene flow. There were no commercial cotton populations within $10 \mathrm{~km}$ of the sites we monitored.

The likelihood of gene flow between commercial cotton and G. tomentosum under current conditions can also be addressed by looking at historical gene flow. Although $G$. tomentosum is the only Gossypium species that is native to the Hawaiian Islands, cultivars of both G. birsutum and G. barbadense were introduced as long ago as the late eighteenth or early nineteenth century (Stephens 1963, 1964, Bates 1990). Cotton is no longer widely grown as an agricultural commodity in $\mathrm{Ha}-$ wai' $\mathrm{i}$, but $G$. barbadense and $G$. birsutum survive as feral escapes from earlier periods of commercial cultivation (Stephens 1964; J.F.W., pers. obs.). Today, naturalized populations of $G$. barbadense can be found "on all the main islands except Kahoolawe and Maui," and G. birsutum is found "at least sparingly naturalized at Haleiwa, Oahu and perhaps elsewhere" (Bates 1990:876). This history of cultivation raises the possibility that historical gene flow has occurred between the introduced species and the Hawaiian endemic. This is suggested by our own morphological observations of floral and leaf characters of putatively introgressant accessions that we have grown in the greenhouse (J.F.W., pers. obs.) and by Stephens (1964), who reported hybridization between $G$. tomentosum and G. barbadense in western $\mathrm{O}^{\prime} \mathrm{ahu}$.

Species-specific allozyme alleles exist in $G$. barbadense, G. birsutum, and G. tomentosum
(DeJoode and Wendel 1992). All accessions of G. tomentosum were inspected for the presence of alleles from G. birsutum and G. barbadense, but there was no clear evidence of introgression. These data do not demonstrate the absence of introgression into G. tomentosum or even into the specific accessions examined; the possibility remains that introgression was not detected due to the relatively small number of diagnostic marker loci employed at that time. A system analogous to that of gene flow from commercial cotton into G. tomentosum on the Hawaiian Islands involves gene flow from commercial cotton into the endemic Gossypium darwinii on the Galápagos Islands. Wendel and Percy (1990), in a study of allozymes, found evidence of limited introgression between $G$. barbadense and $G$. darwinii. A more powerful molecular marker technology, AFLP (Amplified Fragment Length Polymorphism), enabled us to detect 11 and 16 species-specific markers for $G$. tomentosum and $G$. birsutum, respectively (Hawkins et al. 2005). No evidence of introgression was detected in a survey of a small number of samples.

Despite the fact that $G$. tomentosum populations have been reduced in size and fragmented and that the native pollinator of $G$. tomentosum appears to be nonexistent, the species appears to be in no danger of disappearing due to lack of pollination. The nonnative honeybees and carpenter bees regularly pollinate the flowers, and fruits were found in all populations. The only downside to having these species as pollinators is the potential for gene flow from transgenic commercial cotton, but this concern can be virtually eliminated if commercial cotton is grown more than $10 \mathrm{~km}$ from $G$. tomentosum populations.

\section{ACKNOWLEDGMENTS}

We thank Ane Bakutis for monthly monitoring of the O'ahu G. tomentosum population and Norm and Linda Nelson for monthly monitoring of the Maui population. We also thank Barbara Pleasants and Kathleen Wendel for help with some of the fieldwork. We 
thank the Environmental Protection Agency for supporting this research.

\section{Literature Cited}

Bates, D. M. 1990. Malvaceae. Pages 868902 in W. L. Wagner, D. R. Herbst, and S. H. Sohmer, eds. Manual of the flowering plants of Hawai'i. University of Hawai'i Press, Bishop Museum Press, Honolulu.

Beismeijer, J., S. P. M. Roberts, M. Reemer, R. Ohlemüller, M. Edwards, T. Peeters, A. Schaffers, S. G. Potts, R. Kleukers, C. D. Thomas, J. Settele, and W. E. Kunin. 2006. Parallel declines in pollinators and insect-pollinated plants in Britain and the Netherlands. Science (Washington, D.C.) 313:351-354.

Cox, P. A., and T. Elmqvist. 2000. Pollinator extinction in the Pacific islands. Conserv. Biol. 14:1237-1239.

Daly, H. V., and K. N. Magnacca. 2003. Hawaiian Hylaeus (Nesoprosopis) bees (Hymenoptera: Apoidea). Insects of Hawai'i. Vol. 17. University of Hawai'i Press, Honolulu.

Darvill, B., M. E. Knight, and D. Goulson. 2004. Use of genetic markers to quantify bumblebee foraging range and nest density. Oikos 107:471-478.

DeJoode, D. R., and J. F. Wendel. 1992. Genetic diversity and origin of the Hawaiian Islands cotton, Gossypium tomentosum. Am. J. Bot. 79:1311-1319.

Ellstrand, N. C., H. C. Prentice, and J. F. Hancock. 1999. Gene flow and introgression from domesticated plants and their wild relatives. Annu. Rev. Ecol. Syst. 30:539-563.

Fryxell, P. A. 1979. The natural history of the cotton tribe. Texas A\&M University Press, College Station.

Hawkins, J. S., J. Pleasants, and J. F. Wendel. 2005. Identification of AFLP markers that discriminate between cultivated cotton and the Hawaiian island endemic, Gossypium tomentosum Nuttall ex Seeman. Genet. Resour. Crop Evol. 52:1069-1078.

Klips, R. A., and A. A. Snow. 1997. Delayed autonomous self-pollination in Hibiscus laevis (Malvaceae). Am. J. Bot. 84:48-53.

Magnacca, K. N. 2007. Conservation status of the endemic bees of Hawai'i, Hylaeus (Nesoprosopis) (Hymenoptera: Colletidae). Pac. Sci. 61:173-190.

Magnacca, K. N., and B. N. Danforth. 2006. Low nuclear DNA variation supports a recent origin of Hawaiian Hylaeus bees (Hymenoptera: Colletidae). Mol. Phylogenet. Evol. 43:908-915.

McKenna, M. A., and J. D. Thomson. 1988. A technique for sampling and measuring small amounts of floral nectar. Ecology 69:1306-1307.

Meyer, J. R., and V. G. Meyer. 1961. Origin and inheritance of nectariless cotton. Crop Sci. 1:167-169.

Moffett, J. O. 1983. Hybrid cotton. Pages 508-514 in C. E. Jones and R. J. Little, eds. Handbook of experimental pollination biology. Van Nostrand Reinhold, New York.

Osborne, J. L., S. J. Clark, and R. J. Morris. 1999. A landscape study of bumblebee foraging range and constancy, using harmonic radar. J. Appl. Ecol. 36:519-533.

Pasquet, R. D., A. Peltier, M. B. Hufford, D. Oudin, J. Saulnier, L. Paul, J. T. Knudsen, H. R. Herren, and P. Gepts. 2008. Longdistance pollen flow assessment through evaluation of pollinator foraging range suggests transgene escape distances. Proc. Natl. Acad. Sci. U.S.A. 105:13456-13461.

Reiger, M. A., M. Lamond, C. Preston, S. B. Powles, and R. T. Roush. 2002. Pollenmediated movement of herbicide resistance between commercial canola fields. Science (Washington, D.C.) 296:23862388.

Seeley, T. D. 1985. Honeybee ecology. Monographs in Behavior and Ecology. Princeton University Press, Princeton, New Jersey.

Snelling, R. R. 2003. Bees of the Hawaiian Islands, exclusive of Hylaeus (Nesoprosopis) (Hymenoptera: Apoidea). J. Kans. Entomol. Soc. 76:342-356.

Stephens, S. G. 1963. Polynesian cottons. Ann. Mo. Bot. Gard. 50:1-22. 
1964. Native Hawaiian cotton (Gos- Wendel, J. F., and R. G. Percy. 1990. Allosypium tomentosum Nutt.). Pac. Sci. zyme diversity and introgression in the 18:385-398.

Swezey, O. H. 1935. Insect fauna of Gossypium tomentosum. Proc. Hawaii. Entomol. Soc. 9:96-98.

Wendel, J. F., and R. C. Cronn. 2003. Polyploidy and the evolutionary history of cotton. Adv. Agron. 78:139-186. Galapagos Islands endemic Gossypium darwinii and its relationship to continental G. barbadense. Biochem. Syst. Ecol. 18:517528. 
